\title{
Complete Albinism in a Northern Red-backed Vole, Myodes rutilus, in Alaska
}

\author{
JACKSON S. WHITMAN
}

Alaska Department of Fish and Game, Division of Wildlife Conservation, Nongame Program, 1300 College Road, Fairbanks, Alaska 99701 USA; e-mail: jlwhitman.idaho@gmail.com

Whitman, Jackson S. 2009. Complete albinism in a Northern Red-backed Vole, Myodes rutilus, in Alaska. Canadian FieldNaturalist 123(2): 167-168.

During a study of small mammal abundance and species composition in interior Alaska, I collected a Northern Red-backed Vole (Myodes rutilus) showing complete albinism. This report documents that extremely rare occurrence, with notes on habitat and morphometrics.

Key Words: Myodes rutilus, Northern Red-backed Vole, albino, Alaska.

True albino, or amelanistic individuals are caused by a genetic trait and are completely devoid of melanin. Characteristicly they have unpigmented pink eyes. Mammals with this trait display white pelage. Albinism, either partial or complete, is rarely documented in wild populations, thus detailed observations are noteworthy.

I captured a single complete albino Northern Redbacked Vole (Myodes rutilus) in a Museum Special snap trap (Woodstream Corporation, Lititz, Pennsylvania, USA) baited with a combination of peanut butter and rolled oats on 2 August 2007 on Minto Flats State Game Refuge, central Alaska $\left(64.9052^{\circ} \mathrm{N}\right.$, $\left.149.0309^{\circ} \mathrm{W}\right)$. Dental characteristics and skull morphology confirmed the initial species classification. The albino Northern Red-backed Vole had complete white pelage and pink eyes, with standard body measurements well within the norm displayed by other conspecifics in interior Alaska. Testes were non-scrotal, indicating a juvenile male individual. Weight was $17.4 \mathrm{~g}$, with standard measurements $(\mathrm{mm})$ of 119:29:
19:14 (total:tail:hind foot:ear). In a sample of 111 individuals captured during 2007, weights averaged 20.9 g, with extremes from 7.9 to $36.7 \mathrm{~g}$. Standard measurements from this population sample show means of 120.0:29.7:18.9:14.4 (Whitman, unpublished data). This specimen was submitted for curation to the University of Alaska Museum of the North (UAM 85050).

During 2003-2007, 7926 trapnights using unmodified Museum Special snap traps resulted in captures of 925 Northern Red-backed Voles. An additional 107 individuals were captured in 980 pitfall trapnights (1 capture/8906 trapnights; 1 albino in 1032 M. rutilus captured $=0.097 \%$ ). No other Northern Red-backed Voles showed any degree of albinism. A check for albinism amongst 1653 Northern Red-backed Vole records in the University of Alaska Museum of the North revealed six specimens, two of which appeared to be complete albinos. However, I suspect any inference to natural population incidence is negated by the fact that pelage morphs are more likely to be curated than "normal" specimens. 
Habitat from which the albino Northern Red-backed Vole came was interior boreal forest at $110 \mathrm{~m}$ elevation. No notable logging or other anthropogenic changes have occurred within $10 \mathrm{~km}$ of the site. Overstory vegetation was composed of an open mixed forest of Alaska Paper Birch (Betula neoalaskana) and White Spruce (Picea glauca) with approximately $50 \%$ canopy closure. The understory (stems per 1-m-radius plot frame) was comprised of Labrador Tea, Ledum groenlandicum ( 90 stems, 59\% of total stems), Mountain Cranberry, Vaccinium vitis-idaea $(30,20 \%)$, Bog Blueberry, Vaccinium uliginosum (22, 14\%), and minor amounts of grass, Calamagrostis sp. (5, 3\%), Horsetail, Equisetum sp. (4, 3\%), and Red-fruited Bastard Toadflax, Geocaulon lividum (2, 1\%). Plant systematics and nomenclature follows Hultén (1968) with updates provided by Viereck and Little (2007). Habitat suitable for Northern Red-backed Voles occurs in a continuum on the north side of the Alaska Range through Alaska and eastward into Yukon Territory, Canada, thus, this individual was not likely from a geographically isolated population.

Although there are numerous references to albinism in various microtine populations (Microtus montanus: Warren 1929; Pinter and Negus 1971; Jannett 1981; M. ochrogaster: Pinter and Negus 1971; M. pennsylvanicus: Owen and Shakelford 1942; Barrett 1975, Brewer et al. 1993, Parsons and Bondrup-Nielsen 1995; M. pinetorum: Schantz 1960; Paul 1964; Clethrionomys (Myodes) gapperi: Bowman and Curran 2000), the incidence (captures/100 trapnights or percentage of total catch) of albinism is rarely reported. As well, most references are of partial albinism or leucism, with few completely albino references. I can provide no plausible argument to suggest that albinistic individuals are not captured in proportion to their occurrence in the population.

\section{Acknowledgments}

M. Rabe assured adequate funding for the project through the State Wildlife Grants program, administered by the Alaska Department of Fish and Game, Wildlife Conservation Division, Nongame Program.
L. Olson and B. Jacobsen at the University of Alaska Museum of the North kindly accepted and expertly curated this and other specimens. A. Greenblat of Shadow Aviation in Fairbanks provided timely and safe transportation. L. Whitman, T. Jung, and one anonymous reviewer provided helpful editorial comments.

\section{Literature Cited}

Barrett, G. 1975. Occurrence of an albino Microtus pennsylvanicus in Ohio. Journal of Mammalogy 75: 102.

Bowman, J., and R. M. Curran. 2000. Partial albinism in the red-backed vole, Clethrionomys gapperi, from New Brunswick. Northeastern Naturalist 7: 181-182.

Brewer, S. R., M. F. Lucas, J. A. Mugnano, J. D. Peles, and G. W. Barrett. 1993. Inheritance of albinism in the meadow vole (Microtus pennsylvanicus). American Midland Naturalist 130: 393-396.

Hultén, E. 1968. Flora of Alaska and neighboring territories: A manual of the vascular plants. Stanford University Press, California. 1008 pages.

Jannett, F. J., Jr. 1981. Albinism and its inheritance in populations of the montane vole. Journal of Heredity 72: 144146.

Owen, R. D., and R. M. Shakelford. 1942. Color aberrations in Microtus and Pitymys. Journal of Mammalogy 23: 306314.

Parsons, G. J., and S. Bondrup-Nielsen. 1995. Partial albinism in an island population of meadow voles, Microtus pennsylvanicus, from Nova Scotia. Canadian Field-Naturalist 109: 263-264.

Paul, J. R. 1964. Second record of an albino pine vole. Journal of Mammalogy 45: 485.

Pinter, A. J., and N. C. Negus. 1971. Coat color mutations in two species of voles (Microtus montanus and Microtus ochrogaster) in the laboratory. Journal of Mammalogy 52: 196-199.

Schantz, V. S. 1960. Record of an albino pine vole. Journal of Mammalogy 41: 129.

Viereck, L. A., and E. L. Little, Jr. 2007. Alaska trees and shrubs. Second edition. University of Alaska Press, Fairbanks, Alaska. 359 pages.

Warren, E. R. 1929. An albino field mouse. Journal of Mammalogy 10: 82 .

Received 26 October 2007

Accepted 8 March 2010 